\title{
Approaches to support disruptive innovations within entrepreneurship education
}

\author{
Ileana HAMBURG \\ IAT, Westfälische Hochschule Gelsenkirchen, Germany \\ hamburg@iat.eu
}

\begin{abstract}
Due to COVID-19, disruptions in many sectors i.e., social, political, labor, economic and education have been produced. Education is one of the key factors for development and also for improving competitiveness and growth of countries. The role of entrepreneurship education and training institutions is to prepare students for entrepreneurial practices and develop entrepreneurship competences. The transition from face-to-face teaching to online ones creates many difficulties for students, educators and institutions to adapt quickly. But the required changes within education due Covid-19 also open the way for new forms of teaching and learning within entrepreneurship education i.e., to develop and use interdisciplinary education forms as well as more practical oriented lifelong learning approaches and use the support of digital learning platforms. This paper presents some consequences of the pandemic in the field of digital teaching and learning models within entrepreneurship education and lifelong learning. Second some improvements are proposed in this context which have been tested by the Lifelong Learning Study Group of the IAT also within European projects.
\end{abstract}

Keywords: Covid-19, Entrepreneurship education, Lifelong learning, Interdisciplinary learning.

\section{Introduction}

Due to COVID-19, disruptions in many sectors i.e., social, political, labor, economic and education have been produced. Education is one of the key factors for development and also for improving competitiveness and growth of countries. Digitalization, intensive participation in the global economy and other demands for individuals and organizations can be supported also by educational and training institutions and by approaches of assure quality education for all. In this context i.e., entrepreneurship education and training institutions should prepare students for entrepreneurial practices and develop entrepreneurship competences. Following Recommendation of the European Parliament and the Council of 18 December 2006 on key competencies for lifelong learning, knowledge, skills and attitudes are key components of a competence and entrepreneurship competence is one of the most important ones (European Commission, 2006, 2007).

Governments have launched emergency policy initiatives to be able to stop the number of infections due to pandemic (Zhang et al., 2020), and continuity of learning and teaching activities remotely through the use of digital technologies. This abrupt way from face-to-face teaching to remote one creates many difficulties also for students, educators and institutions to adapt quickly to the new context based on digital approaches.

Referring education, often necessary knowledge is not existing within curriculum of professions and disciplines within a formal system; lifelong learning (LLL) serves to complete such gaps within formal systems or in case of disruptions like that due to COVID-19 in order to improve the learning process; LLL is very important for professional development within all professions and can be done within formal, non-formal or informal education approaches.

Additional to the pandemic disruptions within all kinds of education, Sustainable Development Goal 4 Education (SDG4) (https://sdgs.un.org/goals) to assure quality education for all and lifelong learning was not supported like planned. 
But the needed changes within education due Covid-19 could be used for creating new forms of teaching and learning within entrepreneurship education i.e., interdisciplinary methods as well as more practical oriented lifelong learning approaches and support of digital learning platforms (Hamburg, 2020a). This paper presents some consequences of the pandemic in the field of teaching and learning models within entrepreneurship education and lifelong learning. Second some improvements proposed in this context have been used by the Lifelong Learning Study Group of the IAT within German and European projects.

PICBE |

585

\section{Lifelong Learning}

Lifelong learning (LLL) is a continuous learning process for people to upgrade knowledge, skills, and competencies, achieve new ones and use them both within their professional as well as social life (Koper \& Tattersall, 2004). Through LLL people gain experience to participate in society more actively. Lifelong learning is an educational philosophy which changes particularly within intensive digital transformation in organizations: people should consider changing attitudes and to be open to new ideas and decisions. In order to survive/be successful due to many digital developments as well as disruptions like this due Covid-19, the existing and future entrepreneurs must be engaged, individually or within the organizations in which they work, on continuous improving of their own knowledge. In this context, it is expected that LLL helps them to solve immediate problems, gain or practice some specific skills when necessary (Fischer \& Konomi, 2007).

Digital developments, social distance due to Covid-19 and disruption of education methods facilitate the use of digital platforms for lifelong learning - digital LLL.

Some important factors to be considered at the development of learning materials for digital LLL are: (Puretta, 2015) determining of advantages and problems with digital technologies, the attitude of students for learning a specific topic, digital skills of educators, structure of content, interaction that takes place between students and teachers, as well as among students (Martinez et al., 2007). In order to increase the benefits of the use of digital learning, besides technology, "experience while using it," "inclusion," and other factors for acquisition of knowledge are important. Another important factor besides to connect LLL with different forms of learning formal, informal, not-formal and to apply digital technologies it to assure for it a content easily to be applied in practice (Puretta, 2015).

\section{Entrepreneurship education}

Educational institutions, besides teaching and learning, support economic and social development also within entrepreneurship education (Barba-Sánchez and Atienza-Sahuquillo 2018). It helps students to achieve necessary skills and develop their entrepreneurial intention (Zhang et al., 2014). There are many entrepreneurship courses offered by higher institutions and other education and training organisations as well as within national and international projects; also, policy makers support entrepreneurship education (Gibb 2011; O'Connor, 2013; Hoppe, 2016) and the European Commission considers "entrepreneurship" as one of the eight important competences (European Commission, 2007).

Many studies about entrepreneurship education refer to a specific field of study or a specific level of education (Barba-Sánchez and Atienza-Sahuquillo, 2018). 
Theories and pedagogical approaches promote interdisciplinary learning, but current academic organizational structures do not offer students tools and methods for integrating knowledge from many disciplines and to build multidisciplinary networks.

Human Capital Theory proposes interdisciplinary teams with members having different backgrounds to foster an innovative mindset (Becker 1994); they have achieved better performances than others (Colombo \& Grille 2005). Reynolds and Lewis (2017) underlie that tteams with participants having different backgrounds solve problems faster. Such interdisciplinary approaches are helpful also for a start-up team, but entrepreneurship programs for students from different fields of study and with different educational levels are missing.

Some results show that an interdisciplinary entrepreneurship course as a special one within university or vocational education and training (VET) or within projects could be easier to be developed, because it is often difficult to overcome university or VET institution policies (Hamburg \& Vladut, 2019). Project team with participants having different competencies, as well as different cognitive and decision-making skills (Thursby et al., 2009) could be created.

The methods used for teaching entrepreneurship are very important; practical-oriented teaching models i.e., using experiential learning (Kassean et al., 2015) seem to be more effective than theoretical ones. Creativity and innovative skills necessary in entrepreneurial activities could be better developed i.e., within a practical-oriented teaching model. Rasmussen and Sørheim (2006) explained that a learning-by-doing approach that allows students to work in teams and cooperate with company's partners or external mentors is very useful. Such entrepreneurship programs give students the possibility to gain experience in a real business context when teams are built. The problem is that due to COVID-19 it is difficult to use experiential learning, learning by doing and other practical-oriented teaching models. Many companies where students have practical places were/are closed. Due also to pandemic time, digital models have continually been adopted in all aspects of life, but digital learning was not very used within entrepreneurship education. The pandemic crisis has accelerated the adoption of digital learning and teaching also within entrepreneurship education, although this has been done in an unplanned manner (https://ec.europa.eu/education/sites/default/files/document-library-docs/deap-swdsept2020_en.pdf).

Some methods which can be used also within teaching and learning in entrepreneurship education are:

- Critical reflection supports learners to gain awareness of their implicit knowledge (Brockbank $\&$ Mc. Gill, 2006). The student reflects based on own learning experience and the role of social context and experience are recognized.

- Intentional learning helps to learn new concepts and skills through practice, is motivated by intentions and is goal directed. Bereiter and Scardamalia (1989) define intentional learning "to refer to cognitive processes that have learning as a goal rather than an incidental outcome". Intentional learning refers to the content of learning, its end product as well as the learning process itself.

- Interdisciplinary Problem-Based Learning (IPBL) which combines Problem-based Learning (PBL), and Interdisciplinary Learning is a suitable approach for innovation (Taradi et al., 2005; Barrows, 2002; O'Brien et al., 2019). IPBL helps students to understand complex problems also regarding social sustainability. It facilitates interdisciplinary thinking and achieving an integrative perspective for scientific and practical solutions. 
- Interdisciplinary Project-Based learning (IPjBL) engages students in gaining interdisciplinary insights, by synthesizing and reflecting and following steps of project management (Brassier, M. \& Dettmers, J., 2017).

By supporting such methods through collaborative digital tools, educators can create active learning environments that make student learning more effective, particularly in interdisciplinary teams. Some tools should be developed which mix productivity and creativity, supporting students to share and collaborate on projects, give and discuss feedback, use brainstorming. The students learn how collaboration supports knowledge building as well as the development of social and emotional skills within teamwork or network. Some examples of tools are the followings.

- CueThink - An innovative, community-based platform that helps students plan, strategize, and collaborate

- Parlay - Comprehensive discussion platform develops critical-thinking skills and help educators to make discussion a central part of their classroom.

- Google Drive

- Microsoft Teams useful particularly within small groups or nontraditional group configurations like in our projects.

These tools support the student flexibility of exploring concepts and acquiring skills through the learning process, by creating new problems, finding solutions.

\section{Problems by the use of digital technology in entrepreneurship education}

Research studies and own projects show gaps in digital competence and knowledge of the use of digital technologies by educators (Espino-Dias, 2020). Educators have a particular role, and digital skills are an important issue in the context of closing education institutions and training as well as companies by using remote learning. There are differences between the competencies that educators need to apply in their digital teaching methods and the ones they have. Educators must be involved in continuous training throughout the pandemic academic year and not only to achieve digital teaching competence but also special ones such as in security and communication. But there are also other problems like a deficit in the creation of digital content and methods. There exist also differences in understanding of importance and necessity to use of digital technologies by educators. Measures have to be taken in this context and also in the management of digital education. Sure, it was not time during this digital emergency to adapt existing curriculum and to develop a methodology for digital teaching.

Digital approaches in entrepreneurship education are necessary for students not only due to pandemic but also because the future entrepreneurs should be prepared for technological change, particularly for digitalization nowadays and should achieve corresponding competences for future workplaces. Until now a digital based entrepreneurship education curriculum was not seen as very important and there has been more investment in development work necessary skills not digital ones within entrepreneurship education. There are also problems with the quality of the resources and materials supporting online learning in entrepreneurship education, the interaction of students with peers and with assessment and accreditation procedures (Vorbach et al, 2018).

\section{Example}

Within national and European projects, the Study Group Lifelong Learning of the IAT, coordinated by the author, analyzed the situation of entrepreneurship education in some European higher institutions, VET and SMEs. The used of interdisciplinary training has been particularly analyzed 
within Cyber Security approaches. Methods for fostering the development and skills of educators from two Universities and VET organizations have been discussed. An interdisciplinary digital training program in Cyber Security for VET is in the development. It will be adapted for a special course for entrepreneurs offered to higher education students. In a present cooperation a digital module for educators in Cyber Security as well as for other interested educators who would like to improve their digital teaching and interdisciplinary competences is in the development.

In a last project, interdisciplinary work-based research competence has been developed within four digital learning modules supported by an interactive digital learning platform for VET institutions and adapted for SMEs. The two used learning methods in this project are Interdisciplinary Problem-Based Learning (IPBL) and Interdisciplinary Project-Based learning (IPjBL). These engaged students in gaining interdisciplinary insights, by synthesizing, reflecting and following steps of project management (Brassler et al., 2017).

The companies and/or the cooperation partner companies of students were closed some months due to Covid-19, so that planned cooperation within own projects in small teams was not very successful within all groups.

Both used methods IPBL and IPjBL supporting collaborative work in team or with other partners/communities have been appreciated positively by learners helping them to understand real-life and interdisciplinary problems and useful for them in their jobs or lives. Also, the digital competences achieved through the digital learning modules have been seen as useful.

\section{Conclusions}

Results showed that the students' entrepreneurial intention and necessity of development of their digital competences increased. Our projects and some short studies done in cooperation with European partners in two universities show that the work in interdisciplinary teams and also with cooperation partners from companies was useful i.e., for building professional networks. The students have also benefitted of lifelong competences like critical thinking, working in teams, achieved within formal- and non-formal education offered facilities, but they need help in this context. Involvement in LLL and the use of digital platforms is also an opportunity to improve their quality of life. Disruptions within education due to pandemic are affecting teaching and learning and educators and students have to find way for the new situation. The educator's role in the effective use of digital tools in the teaching process is important during and after the COVID-19 crisis (Hamburg, 2020b). Within entrepreneurship education as well in all education forms it is necessary to develop and implement contingency plans, such as alternative education pathways, to mitigate pandemic impacts. Coordination measures are necessary also within digital education because there are many actors needed to respond to and mitigate the impact of crises and this can lead to duplication, inefficiency, and confusion. Education should suffer innovative digital disruptions (Christensen et al., 2008; Hamburg, 2020b) and positive changes in teaching and learning should be accelerated. Disruptions caused by Covid-19 and quickly use of digital technology in education should determine educators, students, corresponding responsible institutions to think and act in new ways, providing opportunities for the changes needed within entrepreneurship education to become innovation drivers. It is necessary that entrepreneurship educators will be better trained; educational agencies should develop and support digital frameworks for entrepreneurship education and help in this direction. More research and case studies about the way educators have included digital lifelong learning approaches into their lessons are needed. Studies about pre- and post-Covid environments should be done to see what has changed or has to be changed in this context, to present positive and negative experiences of 
entrepreneurship educators and to discuss how pandemic and digital context influenced teaching and learning methods (Espino-Diaz, 2020). More research referring different geographic contexts is necessary to determine how a country level of pandemic, country economic situation, the use of digitalization and lifelong learning influenced entrepreneurship education.

\section{References}

Barba-Sánchez, V. \& Atienza-Sahuquillo, C. (2018). Entrepreneurial intention among engineering students: The role of entrepreneurship education, European Research on Management and Business Economics, 24, 53-61.

Barrows, H. (2002). Is it Truly Possible to Have Such a Thing as dPBL?, Distance Education, 23:1, 119-122, DOI: 10.1080/01587910220124026.

Becker, G. S. (1994). Human capital revisited. In Human Capital: A Theoretical and Empirical Analysis with Special Reference to Education, $3^{\text {rd }}$ ed. Chicago, The University of Chicago Press, 15-28.

Bereiter, C., \& Scardamalia, M. (1989). Intentional learning as a goal of instruction. In L. B. Resnick (Ed.), Knowing, learning, and instruction: Essays in honor of Robert Glaser, 361-392, Hillsdale, Lawrence.

Brockbank, A., \& McGill, I. (2006). Facilitating Reflective Learning Through Mentoring \& Coaching. London, Kogan Page Publishers, 27.

Brassier, M., \& Dettmers, J. (2017). How to Enhance Interdisciplinary Competence Interdisciplinary Problem-Based Learning versus Interdisciplinary Project-Based Learning, Interdisciplinary Journal of Problem-Based Learning, 11(2), 67-80.

Christensen, C.M., Johnson, C., \& Horn. B. (2008). "Disrupting class: How disruptive innovation will change the way the world learns", McGraw-Hill, New York, 2008.

Colombo, M. G., \& Grilli, L. (2005). Founders' human capital and the growth of new technologybased firms: A competence-based view, Research Policy, 34, 795-816.

Espino-Díaz, L. (2020). Analyzing the Impact of COVID-19 on Education Professionals. Toward a Paradigm Shift: ICT and Neuroeducation as a Binomial of Action.

European Commission (2006). Recommendation of the European Parliament and of the Council of 18 December 2006 on key competences for lifelong learning, Official Journal of the European Union 30: L394/310.

European Commission (2007). Key competences for lifelong learning, European Reference Framework. European Commission, Retrieved from: http://ec.europa.eu/dgs/education_ culture/publ/pdf/ll-learning/keycomp_en.pdf.

Fischer, G., Konomi, S. (2007). Innovative socio-technical environments in support of distributed intelligence and lifelong learning, Journal of Computer Assisted Learning, 23, 338-350.

Gibb, A. (2011). Concepts into practice: Meeting the challenge of development of entrepreneurship educators around an innovative paradigm: The case of the International Entrepreneurship Educators' Programme (IEEP), International Journal of Entrepreneurial Behavior \& Research 17, 146-165.

Hamburg, I. (2020a). Facilitating lifelong learning in SMEs towards SDG4. Advances in social sciences research journal 7, no. 9, 262-272.

Hamburg, I. (2020b). Creating innovative structures in workplace and vocational digital learning to ensure social distancing. ICDS 2020: The fourteenth international conference on digital society. ISBN: 978-1-61208-760-3, 124-127. 
Hamburg, I., \& Vladut, G. (2019). Developing workplace research skills to bridge the innovation gap between university and industry. In: Advances in social sciences research journal 6, no. $1,144-152$.

Hamburg, I. (2021). Social measures and disruptive innovations in entrepreneurship education to cope with COVID-19. In: Advances in social sciences research journal 8, no. 1, 70-80. Harvard Business Review 30, Available online: https://hbr.org (accessed on 10 January 2019).

PICBE |

Hoppe, M. (2016). Policy and entrepreneurship education, Small Business Economics, 46, 13-29.

Kassean, H., Vanevenhoven, J., Liguori, E. \& Winkel, D.E. (2015). Entrepreneurship education:

A need for reflection, real-world experience and action, International Journal of Entrepreneurial Behavior \& Research, 21, 690-708.

Koper, R. \& Tattersall, C. (2004). New directions for lifelong learning using network technologies, British Journal of Educational Technology 35, 689-700.

Martinez, R. A., del Bosch M., Herrero M. \& Nuno A. (2007). Psychopedagogical components and processes in e-learning. Lessons from an unsuccessful on-line course Computers in Human Behavior, Vol. 23, 146-161.

O’Connor, A. (2013). A conceptual framework for entrepreneurship education policy: Meeting government and economic purposes, Journal of Business Venturing, 28, 546-63.

O'Brien, E., McCarthy, J., Hamburg, I. \& Delaney, Y. (2019). Problem-based learning in the Irish SME workplace, Journal of workplace learning, 31(6), 391-407.

Puretta, I. (2015). Lifelong Learning Process using Digital Technology, Interdisciplinary Management Research, Vol. 11.

Rasmussen, E.A. \& Sørheim, R. (2006). Action-based entrepreneurship education, Technovation 26, 185-94. [CrossRef]

Reynolds, A. \& Lewis, D. (2017). Teams Solve Problems Faster When They're More Cognitively Diverse.

Taradi, S., Taradi, M., Radic, K. \& Pokrajac, N. (2005). Blending problem-based learning with Web technology positively impacts student learning outcomes in acid-base physiology, Advances in Physiology Education, 29, 35-39, doi:10.1152/advan.00026.2004.

Thursby, M.C., Fuller, A.W. \& Thursby, J. (2009). An integrated approach to educating professionals for careers in innovation, Academy of Management Learning and Education 8, 389-406.

Vorbach, S., Poandl, E. M., \& Korajman, I. (2019). Digital Entrepreneurship Education - The Role of MOOCs, International Journal of Engineering Pedagogy, 9(3).

Zhang, W., Wang, Y., Yang, L., Wang, C. (2020). Suspending Classes Without Stopping Learning: China's Education Emergency Management Policy in the COVID-19 Outbreak, J. Risk Financ. Manag., 13, 55. 